\title{
Setting up a polymerase chain reaction assay for the detection of toxic cyanobacteria
}

\author{
D.N. Magana-Arachchi*, R.P. Wanigatunge and P. Jeyanandarajah \\ Institute of Fundamental Studies, Hantana Road, Kandy.
}

Revised: 23 September 2007 ; Accepted: 23 January 2008

\begin{abstract}
Cyanobacteria are aquatic and photosynthetic prokaryotes which form harmful algal blooms under certain conditions. Water blooms of cyanobacteria from the genus Microcystis are of increasing concern due to their production of microcystin, a cyclic heptapeptide which is formed nonribosomally by peptide and polyketide synthetases. A number of studies have targeted the PCR amplification of microcystin synthetase gene cluster for the identification of toxic cyanobacteria, both in cultivated strains and environmental samples. In this study, water samples collected from seven sites and the cultures originated from the cyanobacterial bloom of the Lake Beira were analyzed by polymerase chain reaction (PCR) using the cyanobacterial specific oligonucleotide primers for the 16S rRNA gene and genus specific oligonucleotide primers for the $m c y \mathrm{E}$ gene. All DNA samples submitted to PCR reactions yielded the unique fragments of about 450 bp for the 16S rRNA gene and 250bp for the $m c y \mathrm{E}$ gene. The results of the BLAST EF051239 showed 98\% of the nucleotide homology to the Microcystis aeruginosa gene of 16S ribosomal RNA and EF051238, 95\% homology to the $m c y$ E gene of $M$. aeruginosa (PCC 7941). These results confirm the presence of microcystin producing $M$. aeruginosa in the Beira Lake and the need for rapid identification of toxin producing cyanobacteria from environmental samples.
\end{abstract}

Keywords; Cyanobacteria, mcy gene, microcystin, Microcystis aeruginosa

\section{INTRODUCTION}

Cyanobacteria are aquatic and photosynthetic prokaryotes which form harmful algal blooms (HAB) under optimal conditions such as high light and calm weather. Mass presence of these organisms in freshwaters is of increasing concern worldwide due to their production of a range of hepatotoxins and neurotoxins. The microcystins, cyclic heptapeptide hepatotoxins, are by far the most prevalent of the cyanobacterial toxins and are produced by strains of distantly related cyanobacterial genera Microcystis, Anabaena, Plankthothrix, and more rarely Anabaenopsis, Hapalosiphon and Nostoc ${ }^{1}$. Hepatotoxins are synthesized and retained in cyanobacterial cells but during bloom senescence and cell lyses they are released into the surrounding water. The incidence of wild and domestic animal poisoning and human health problems attributed to exposure to cyanobacterial toxins have been well documented ${ }^{2}$.

Microcystins have the common structure cyclo(D-Ala-L-X-D-MeAsp-L-Z-Adda-D-Glu-Mdha), where $\mathrm{X}$ and $\mathrm{Z}$ are variable $\mathrm{L}$ amino acids, Adda is 3 amino -9-methoxy-2,6,8-trimethyl-10-phenyl-4,6-decadienoic acid, D-MeAsp is 3-methyl aspartic acid and Mdha is $\mathrm{N}$ methyldehydro-alanine ${ }^{3}$. More than 70 structural variants of microcystins are known today ${ }^{4}$. Biochemical and genetic studies have shown a mixed polyketide synthase (PKS) / nonribosomal peptide synthetase (NRPS) origin for the microcystins ${ }^{5}$. Microcystin biosynthetic gene cluster (McyA-J) has a modular structure, each module activating and incorporating specific constituents of the heptapeptide ${ }^{6}$. The mcy gene cluster in Microcystis comprises 10 bi directionally transcribed genes ${ }^{5,7}$.

Identification of a cyanobacterial genus by microscopic morphology and / or molecular analysis does not indicate the potential for toxin production. Different strains of one species can be morphologically identical but differ in toxigenicity ${ }^{8}$. The most common methods for monitoring microcystin concentrations have been high performance liquid chromatography (HPLC) combined with a UV-visible light diode array detector, protein phosphatase inhibition and enzyme linked immunosorbent assays (ELISA) ${ }^{9}$. But their analysis does 
not indicate which cyanobacteria produce the toxins, since several genera of cyanobacteria may produce similar microcystin variants ${ }^{1}$.

Many investigators have used PCR based methods for the direct detection and identification of toxigenic strains in bloom samples ${ }^{8}$. Phycocyanin intergenic spacer region between the genes for the $\beta$ and $\alpha$ subunits of the phycocyanin operon ${ }^{10,}{ }^{11}$, the $16 \mathrm{~S}-23 \mathrm{~S}$ rRNA internally transcribed spacer region ${ }^{12}$ are some of the examples that used DNA amplifications to detect potential toxicity in cyanobacteria. A number of studies have targeted the PCR amplification of microcystin synthetase (mcy) gene cluster for the identification of toxic Microcystis strains ${ }^{13}$ and this has enabled the development of specific oligonucleotide primers for genes common to production of all microcystins ${ }^{14,15}$. The $m c y \mathrm{E}$ gene, which encodes the glutamate activating adenylation domain can be used as a surrogate for microcystin - producing cyanobacteria ${ }^{13}$.

The Beira Lake is situated within the city of Colombo, and covers $653,000 \mathrm{~m}^{2}$ with a catchment area of $448,000 \mathrm{~m}^{2}$. It has a history of severe cyanobacterial blooms. Previous reports from Sri Lanka on water blooms have revealed the occurrence of toxic cyanobacteria, and a study by Jayatissa et al. ${ }^{16}$ showed the presence of Microcystis spp. in fresh water bodies of Sri Lanka, including the Beira Lake.

In May 2006, Sri Lankan media reported the deaths of a large number of fish and the presence of a heavy growth of algae in the Beira Lake. Therefore, this study was undertaken to determine the value of using specific DNA amplification techniques for the direct detection of toxigenic strains of toxin producing cyanobacteria from environmental samples.

\section{METHODS AND MATERIALS}

Water samples from the Beira Lake, Colombo (6 $6^{0} 56^{\prime} \mathrm{N} \&$ $79^{\circ} 51^{\prime} \mathrm{E}$ ) were collected in sterile brown glass containers $(2.5 \mathrm{~L})$ on $24^{\text {th }}$ May 2006 . The collections were carried out at seven sites, both on the surface and down the water column $(0.1 \& 1 \mathrm{~m})$ so that they represent the whole water body.

For culture, samples were concentrated by centrifugation ( $3500 \mathrm{rpm}, 10 \mathrm{~min}$ ) and the resulting pellet was serially diluted and inoculated onto BG11 medium and modified BG11 medium. Microscopic observations were made from the field samples. The culture plates and culture bottles were incubated at $28^{\circ} \mathrm{C}$ with 16 - light dark cycling. The standard strains used in this study were obtained from the Pasteur Culture Collection (PCC),
France. Lyngbya (PCC 8937), a filamentous non toxin producing strain and Microcystis aeruginosa (PCC 7941), a unicellular toxin producing strain were maintained in modified BG11 medium ${ }^{17}$.

Cyanobacterial cells from the culture as well as $500 \mu \mathrm{L}$ pellets obtained from environmental samples were transferred to $500 \mu \mathrm{l}$ of $1 \mathrm{xTE}$ buffer and three sequential heating (at $99{ }^{\circ} \mathrm{C}$ for $5 \mathrm{~min}$ ) and freezing (at $-5^{\circ} \mathrm{C}$ for $5 \mathrm{~min}$ ) achieved lyses. Samples were centrifuged $(12,000 \mathrm{rpm}, 5 \mathrm{~min})$ and to each resulting pellet, $40 \mu \mathrm{L}$ of TES and $20 \mu \mathrm{L}$ of lysozyme $(10 \mathrm{mg} / \mathrm{mL})$ was added, and incubated for $1 \mathrm{~h}$ at $37^{\circ} \mathrm{C}$. Cells were then treated with $10 \mu \mathrm{L}$ of proteinase $\mathrm{K}(20 \mathrm{mg} / \mathrm{mL})$ and $40 \mu \mathrm{L}$ of TE/ SDS and incubated at $55^{\circ} \mathrm{C}$ for $2 \mathrm{~h}$ to lyse the organisms further. Subsequently, proteinase $\mathrm{K}$ was inactivated by heating the sample at $95^{\circ} \mathrm{C}$ for $10 \mathrm{~min}$. Finally, nucleic acids were purified by Boom's method ${ }^{18}$ using silica particles and guanidium isothiocyanate.

DNA amplification was performed for the 16S rRNA gene using the modified protocol of Nübel et al. ${ }^{19}$ and cyanobacterial specific primers, forward primer Cya 359F (5'-GGGGAATYTTCCGCAATGGG-3') and the reverse primer Cya 781Ra(5'-GACTACTGGGGTATCTAATCCC ATT-3'), or the reverse primer Cya781Rb (5'GACTACAGGGGTATCTAATCCCTTT-3') or an equimolar mixture of reverse primers Cya781Ra + Cya $781 \mathrm{Rb}^{19}$. Reaction mixtures contained 75 picomoles of each primer, $25 \mathrm{nmol}$ of each deoxynucleoside triphosphate, $10 \mu \mathrm{L}$ of $10 \mathrm{xPCR}$ buffer $(100 \mathrm{mM}$ Tris $-\mathrm{HCl}$ [pH9.0], $15 \mathrm{mM} \mathrm{MgCl}_{2}, 500 \mathrm{mM} \mathrm{KCl}, 1 \%$ [v/v] Triton X -100, 0.5U of SuperTaq DNA polymerase (HT Biotechnology Ltd., Cambridge, UK) and template DNA. The standard DNA used was the DNA extracted from Lyngbya (PCC 8937) and M. aeruginosa (PCC 7941). Amplifications were carried out in $100 \mu \mathrm{L}$ volumes in a Perkin-Elmer/ Cetus DNA Thermal Cycler with a single cycle of $5 \mathrm{~min}$ at $94^{\circ} \mathrm{C}, 1 \mathrm{~min}$ at $60^{\circ} \mathrm{C}$, and $1 \mathrm{~min}$ at $72^{\circ} \mathrm{C}$, followed by 35 incubation cycles each consisting of $1 \mathrm{~min}$ at $94^{\circ} \mathrm{C}, 1 \mathrm{~min}$ at $60^{\circ} \mathrm{C}$, and $1 \mathrm{~min}$ at $72^{\circ} \mathrm{C}$ followed by 15 min extension of $72^{\circ} \mathrm{C}$. Aliquots of the resulting $448 \mathrm{bp}$ sequences were electrophoresed in $1.5 \%$ agarose gels containing $10 \mu \mathrm{gmL}^{-1}$ ethidium bromide and documented through a Polaroid instant camera.

DNA amplification was performed for the $m c y \mathrm{E}$ gene using the modified protocol of Vaitomaa et al..$^{13}$ and general microcystin synthetase gene $\mathrm{E}$ forward primer mcyE-F2 (5'-GAAATTTGTGTAGAAGGTGC-3') and the gene specific reverse primer for Microcystis MicmcyER8 (5' -CAATGGGAGCATAACGAG-3') ${ }^{13}$. Reaction mixtures contained $0.4 \mu \mathrm{M}$ of each primer, $0.1 \mathrm{mM}$ of each deoxynucleoside triphosphate, $10 \mu \mathrm{L}$ of $10 x \mathrm{PCR}$ 
buffer $(50 \mathrm{mM}$ Tris $-\mathrm{HCl}$ [pH 8.0$], 25 \mathrm{mM} \mathrm{MgCl}_{2}$, $100 \mathrm{mM} \mathrm{NaCl}, 0.1 \mathrm{mM}$ EDTA, 1mM DTT, 50\% glycerol, $1 \%[\mathrm{v} / \mathrm{v}]$ Triton X -100), 1.0U of Taq DNA polymerase (Promega, Madison, Wisconsin, USA) and template DNA. The standard DNA used was the DNA extracted from $M$. aeruginosa (PCC 7941). Amplifications were carried out in $100 \mu \mathrm{L}$ volumes in a Perkin-Elmer/ Cetus DNA Thermal Cycler with 35 incubation cycles each consisting of $1 \mathrm{~min}$ at $94^{\circ} \mathrm{C}, 1 \mathrm{~min}$ at $59^{\circ} \mathrm{C}$, and $1 \mathrm{~min}$ at $72^{\circ} \mathrm{C}$ followed by $15 \mathrm{~min}$ extension of $72^{\circ} \mathrm{C}$. Aliquots of the resulting $\sim 250 \mathrm{bp}$ sequences were electrophoresed in $1.5 \%$ agarose gels containing $10 \mu \mathrm{gmL}^{-1}$ ethidium bromide and documented through a Polaroid instant camera.

The visualized PCR fragments were excised and purified using genElute ${ }^{\mathrm{TM}}$ Gel extraction Kit (SIGMA) according to the manufacturer's instructions. The PCR fragments for the $16 \mathrm{~S}$ rRNA and $m c y \mathrm{E}$ genes were sequenced using the MegaBase 1000 (GE Healthcare Biosciences). The obtained sequences were surveyed in the GenBank using Blastn ${ }^{\circledR 2}$. The nucleotide sequences were deposited in GenBank under accession numbers EF051238 and EF051239.

\section{RESULTS AND DISCUSSION}

In this study, a method based on the PCR technique and genus specific $m c y \mathrm{E}$ primers ${ }^{13}$ was used to detect the microcystin producer in the Beira Lake. When the samples from seven sites were subjected to microscopic examination, Microcystis sp. was recorded as the dominant cyanobacterial species in the water body. The second species recorded was Spirulina sp. which was comparatively very low in numbers.

The method employed for genomic DNA extraction resulted in high quality DNA in satisfactory amounts

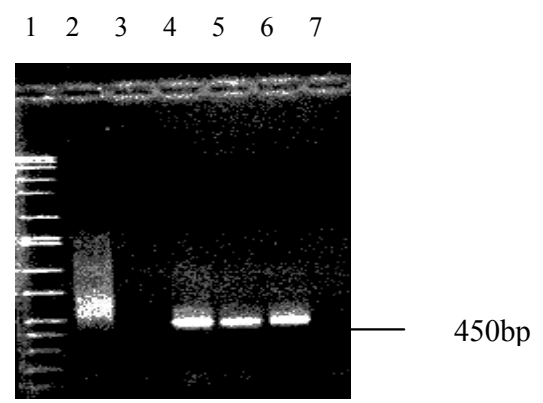

Figure 1a: Detection of cyanobacteria with 16S rRNA gene. Lane 1:DNA marker; 2,3,4: M. aeruginosa standard with equimolar reverse primer mixture $\mathrm{Ra}+\mathrm{Rb}, \mathrm{Ra}$ and $\mathrm{Rb} .5$ : water sample from site 7 with primer $\mathrm{Rb}(\mathrm{bl} \mathrm{7)}$. 6: toxic strain from the culture (bl 7). 7: negative control for amplification. All DNA samples submitted to PCR reactions from the water samples collected from the Lake Beira for the 16S rRNA gene yielded the unique fragment of about $450 \mathrm{bp}$, using the cyanobacterial specific oligonucleotide primers of Cya 359F forward and Cya $781 \mathrm{Rb}$ reverse (Figure 1a). According to the advice given by Boutte et al..$^{21}$ we used the cyanobacterial specific reverse primers Cya $781 \mathrm{Ra}$ and Cya $781 \mathrm{Rb}^{19}$ separately and also in eqimolar mixtures to determine the cyanobacterial community composition in the Beira Lake. The study by Boutte et $a l .{ }^{21}$ showed that the primers Ra and $\mathrm{Rb}$ target filamentous and unicellular cyanobacteria, respectively in a cyanobacterial community. The use of the forward primer Cya $359 \mathrm{~F}$ and the reverse primer Cya $781 \mathrm{Ra}$, as well as Cya 359F and the equimolar mixture of Cya $781 \mathrm{Ra}+$ Cya 781Rb did not yield the fragment of $450 \mathrm{bp}$. In our study, only the reverse primer $\mathrm{Rb}$ yielded the unique fragment for the environmental samples indicating the dominance of unicellular/colonial nature of the Microcystis species in the algal bloom.

A single amplification product was observed when genomic DNA from the standard microcystin - producing $M$. aeruginosa (PCC 7941) was used as a template in PCR with Microcystis genus specific primers. All DNA samples submitted to PCR reactions both from the water samples collected from the Beira Lake and from the cultured isolates originated from water samples for the $m c y \mathrm{E}$ gene, yielded the unique fragment of about $250 \mathrm{bp}$, using the microcystin synthetase gene E forward primer ( $m c y \mathrm{E}-\mathrm{F} 2)$ and genus specific reverse primer for Microcystis (MicmycE-R8) (Figure1b). The results of the BLAST of EF051239 showed $98 \%$ of the nucleotide homology to the $M$. aeruginosa gene for $16 \mathrm{~S}$ ribosomal

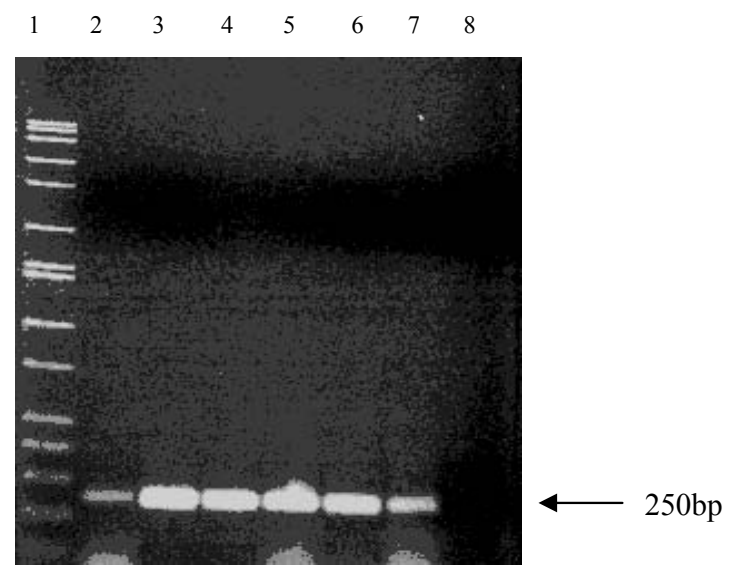

Figure 1b: Detection of toxic cyanobactria using $m c y \mathrm{E}$ gene. Lane 1: DNA marker. 2,3,4: PCR product from water samples, (bl1, b14, \& b17). 5 \& 6: toxic strains from cultures (b14 \& b17). 7: DNA control. 8: negative control 
RNA, partial sequence of AB 271211 while EF051238 showed $95 \%$ homology to the mcyE gene of Microcystis aeruginosa PCC 7941 ( AY382536.1). Therefore the presence of the gene $m c y \mathrm{E}$ in the analyzed water samples/ cultures originating from water samples indicates that the cyanobacterial strains have the genetic potential to produce microcystins.

Previous analysis using the technique of high performance liquid chromatography (HPLC), recorded $0.737 \mu \mathrm{gL}^{-1}$ concentration of microcystins in water samples collected from the Beira Lake in $2000^{16}$. A study in $2002^{8}$ has shown that the PCR assays, applied directly to environmental samples, were as sensitive as HPLC in providing a useful indicator of toxicity. The PCR based assays detect toxigenic cells rather than toxins and require little sample preparation and modest capital costs. Comparatively the DNA amplification technique described in this study does not require a large capital. This is the first study in Sri Lanka which used molecular markers and DNA sequencing to identify toxin generating strains of cyanobacteria in environmental water samples. Being a developing country, Sri Lanka is unable to make large investments for monitoring water quality. Therefore, molecular techniques combined with microscopy can be used to rapidly determine the presence of toxigenic cyanobacterial species in environmental samples.

Cyanobacteria grow best in non turbulent, warm rivers, lakes and reservoirs. Microcystis occasionally forms a bloom, or dense aggregation of cells, that floats on the surface of the water forming a thick layer or 'mat'. Blooms usually occur during the warmest months of the year, especially when the water contains an over abundance of nitrogen $(\mathrm{N})$ and phosphorus (P). Excessive P most often provides the stimulus for cyanobacterial blooms, especially if the total $\mathrm{N}$ to total $\mathrm{P}$ concentration ratio is less than $10^{22}$. According to the data of the Ports Authority of Sri Lanka, (CLEAN), on the day when an excessive fish death on the lake was observed, the total $\mathrm{N}$ to total $\mathrm{P}$ concentration ratio was around 1.9 [nitrate, $1.5 \mathrm{mg} \mathrm{L}^{-1}\left(\max -5 \mathrm{mg} \mathrm{L}^{-1}\right)$ and phosphate, $0.8 \mathrm{mg} \mathrm{L}^{-1}\left(\mathrm{max}-0.4 \mathrm{mg} \mathrm{L}^{-1}\right)$ ] which was less than 10. Therefore, it is possible that the excessive $\mathrm{P}$ in the lake has stimulated the cyanobacterial growth.

Cyanobacterial blooms potentially affect water quality as well as the health of human and animal life. Decomposition of large blooms can lower the concentration of dissolved oxygen in the water, resulting in hypoxia (low oxygen) or anoxia (no oxygen). Wild animal poisonings can occur after ingestion of cyanobacterial biomass and intake of toxins during drinking and feeding. In the case of fish deaths, the causes could be toxins in the cyanophyte, depletion of oxygen in the water, by the liberation of hydrogen sulphide and ammonia caused by cell decomposition or by clogging of the gills.

The results obtained from the study confirms the presence of microcystin producing $M$. aeruginosa in the Beira Lake and the usefulness of molecular biological techniques for the rapid identification of toxin producing cyanobacteria from environmental samples.

\section{Acknowledgement}

We are grateful to Prof. I.Ahmad of the University of Nebraska Medical Center, Nebraska, USA for gifting the necessary primers, to Prof. E.Karunanayake of the Institute of Biochemistry, Molecular Biology \& Biotechnology (IBMBB), University of Colombo for providing the DNA sequencing facility and to Prof. A.Kovoor for valuable guidance.

\section{Reference}

1. Sivonen K. \& Jones G. (1999). Toxic Cyanobacteria in water. In: A Guide to Their Public Health Consequences, Monitoring and Management. (Eds. I. Chorus \& J. Bartram) pp.41-111.Spoon, London, UK.

2. Mazur H. \& Plinski M. (2001). Stability of cyanotoxins, microcystin-LR, microcystin-RR and nodularin in seawater and BG-11 medium of different salinity. Oceanologia 43 (3): 329-339.

3. Carmichael W.W., Beasley V., Bunner D.L., Eloff J.N., Falconer I., Gorham P., Harada K., Krishnamurthy T., Yu M.J. \& Moore R.E. (1988). Naming of cyclic heptapeptide toxins of cyanobacteria (blue-green algae). Toxicon 26(11): 971-973.

4. Kurmayer R., Christiansen G. \& Chorus I. (2003). The abundance of microcystin-producing genotypes correlates positively with colony size in Microcystis sp. and determines its microcystin net production in Lake Wannsee. Applied and Environmental Microbiology 69(2): 787-795.

5. Tillett D., Dittmann E., Erhard M., von Döhren H., Börner T. \& Neilan B.A. (2000). Structural organization of microcystin biosynthesis in Microcystis aeruginosa PCC 7806: an integrated peptide- polyketide synthetase system. Chemistry \& Biology 7:753-764.

6. Dittamann E., Neilan B.A., Erhard M., von Döhren H. \& Börner T. (1997). Insertional mutagenesis of a peptide synthetase gene that is responsible for hepatotoxin production in the cyanobacterium Microcystis aeruginosa PCC 7806. Molecular Microbiology 26: 779-787.

7. Nishizawa T., Asayama M., Fujii K., Harada K. \& Shirai M. (1999). Genetic analysis of the peptide synthetase genes for a cyclic heptapeptide microcystin in Microcystis spp. The Journal of Biochemistry 126: 520-526. 
8. Baker J. A., Entsch B., Neilan B. A. \& McKay D.B. (2002). Monitoring changing toxigenicity of a cyanobacterial bloom by molecular methods. Applied and Environmental Microbiology 68(12): 6070-6076.

9. Via-Ordorika L., Fastner J., Kurmayer R., Hisbergues M., Dittamann E., Komarek J., Erhard M. \& Chorus I. (2004). Distribution of microcystin - producing and non - microcystin - producing Microcystis sp. in European freshwater bodies: detection of microcystins and microcystin genes in individual colonies. Systematic and applied microbiology 27: 592-602.

10. Baker J. A., Neilan B.A., Entsch B. \& McKay D.B. (2001). Identification of cyanobacteria and their toxigenicity in environmental samples by rapid molecular analysis. Environmental Toxicology 16:472-482.

11. Neilan B.A., Jacobs D. \& Goodman A.E. (1995). Genetic diversity and phylogeny of toxic cyanobacteria determined by DNA polymorphisms within the phycocyanin locus. Applied and Environmental Microbiology 61:3875-3883.

12. Neilan B.A., Stuart J.L., Goodman A.E., Cox P.T. \& Hawkins P.R. (1997). Specific amplification restriction polymorphisms of the cyanobacterial rRNA operon spacer region. Systematic and Applied Microbiology 20:612-621.

13. Vaitomaa J., Rantala A., Halinen K., Rouhiainen L., Tallberg P., Mokelke L. \& Sivonen K. (2003). Quantitative Real - Time PCR for determination of Microcystin Synthetase E copy numbers for Microcystis and Anabaena in lakes. Applied and Environmental Microbiology 69(12): 7289-7297.

14. Janse I., Kardinaal W.E.A., Meima M., Fastner J., Visser P.M. \& Zwart G. (2004). Toxic and nontoxic Microcystis colonies in natural populations can be differentiated on the basis of rRNA gene internal transcribed spacer diversity. Applied and Environmental Microbiology 70(7): 3979-3987.

15. Rantala A., Fewer D.P., Hisbergues M., Rouhiainen L., Vaitomaa J., Börner T. \& Sivonen K. (2004). Phylogenetic evidence for the early evolution of microcystin synthesis. Proceedings of the National Academy of Sciences 101(2): 568-573.

16. Jayatissa L.P., Silva E.I.L., McElhiney J. \& Lawton L.A. (2006). Occurrence of toxigenic cyanobacterial blooms in freshwaters of Sri Lanka. Systematic and Applied Microbiology 29(2): 156-164.

17. Rippka R., Deruelles J., Waterbury J.B., Herdman M. \& Stanier R.Y. (1979). Generic assignments, strain histories and properties of pure cultures of cyanobacteria. Journal of General Microbiology 111: 1-61.

18. Boom R., Sol C.J.A., Salimans M.M., Jansen C.L., Wertheim -vanDillen P.M.E. \& Noordaa J. (1990). Rapid and simple method for purification of nucleic acids. Journal of Clinical Microbiology 28(3): 495-503.

19. Nübel U., Garcia-Pichel F. \& Muyzer G. (1997). PCR primers to amplify $16 \mathrm{~S}$ rRNA genes from cyanobacteria. Applied and Environmental Microbiology 63(8): 33273332.

20. Altschul S.F., Madden T.L., Schaffer A.A., Zhang J., Zhang Z., Miller W. \& Lipman D.J. (1997). Gapped BLAST and PSI-BLAST: a new generation of protein database search programs. Nucleic Acids Research 25: 3389-3402.

21. Boutte C., Grubisic S., Balthasart P. \& Wilmotte A. (2006). Testing of primers for the study of cyanobacterial molecular diversity by DGGE. Journal of Microbiological Methods 65(3): 542-550.

22. www.envirologix.com/library/KU_Manuscript_Toxic_ Algae.pdf. Accessed on 20.03.2007. 